\title{
Influenza or other respiratory viruses: does it matter as the cause of acute respiratory failure in the critically-ill patients?
}

\author{
Burçin HALAÇLI ${ }^{1}(\| \mathrm{D})$ \\ Pervin $\mathrm{HANCI}^{2}(\mathrm{ID})$ \\ Ebru ORTAC ERSOY ${ }^{1}$ (ID) \\ Serpil ÖCAL ${ }^{1}(I D)$ \\ Mine Durusu \\ TANRIÖVER $^{3}(I D)$ \\ Arzu TOPELi ${ }^{1}($ ID $)$
}

${ }^{1}$ Department of Internal Medicine, Division of Intensive Care Medicine, Hacettepe University Faculty of Medicine, Ankara, Turkey

${ }^{1}$ Hacettepe Üniversitesi Tıp Fakültesi, İ̧ Hastalıkları Anabilim Dalı, Yoğun Bakım Bilim Dalı, Ankara, Türkiye

2 Intensive Care Unit, Erzurum Regional Training and Research Hospital, Erzurum, Turkey

2 Erzurum Bölge Eğitim ve Araştırma Hastanesi, Yoğun Bakım Ünitesi, Erzurum, Türkiye

${ }^{3}$ Department of Internal Medicine, Division of General Internal Medicine, Hacettepe University Faculty of Medicine, Ankara, Turkey

${ }^{3}$ Hacettepe Üniversitesi Tıp Fakültesi, Iç Hastalıkları Anabilim Dalı, Genel Dahiliye Bilim Dalı, Ankara, Türkiye
Cite this article as: Halaçlı B, Hancı P, Ortaç Ersoy E, Öcal S, Tanriöver MD, Topeli A. Influenza or other respiratory viruses: does it matter as the cause of acute respiratory failure in the critically-ill patients? Tuberk Toraks 2020;68(4):388-398.

\section{Yazışma Adresi (Address for Correspondence)}

\section{Dr. Arzu TOPELI}

Hacettepe Üniversitesi Tıp Fakültesi,

Iç Hastalıkları Anabilim Dalı,

Yoğun Bakım Bilim Dalı,

ANKARA - TÜRKIYE

e-mail: atopeli@hacettepe.edu.tr

CCopyright 2020 by Tuberculosis and Thorax.

Available on-line at www.tuberktoraks.org.com

\begin{abstract}
Influenza or other respiratory viruses: does it matter as the cause of acute respiratory failure in the critically-ill patients?

Introduction: Respiratory virus infections may cause serious respiratory failure requiring intensive care unit (ICU) admission. The objective of this study was to evaluate the clinical features and the outcome in patients with acute respiratory failure $(A R F)$ due to viral infections comparing etiological agents.

Materials and Methods: ARF patients with positive viral serology were retrospectively recruited. Cohort was evaluated with regard to subgroups as influenza and other respiratory viruses (ORV), as well as survivors and nonsurvivors.

Results: Out of 938 admitted patients, 319 were followed as ARF and only 149 patients had viral respiratory panel results. In 49 patients with ARF, 52 positive viral results were detected and 47 patients with single positive viral isolates of either influenza or ORV were included. Among them, $62 \%$ had ORV with quite similar characteristics with influenza group apart from diabetes mellitus which was encountered more in influenza group $(p=0.02)$. Overall ICU mortality was $32 \%$ and there was no difference between the two groups ( $p=0.42$ ). Acute Physiology and Chronic Health Evaluation (APACHE) II score was independently associated with ICU mortality (OR: 1.25; 95\% Cl: $1.04-1.51 ; p=0.02$ ).
\end{abstract}


Conclusion: This study emphasizes to consider the possibility of other respiratory viruses for the cause of ARF with similar characteristics and mortality as influenza species.

Key words: Pneumonia; lower respiratory tract infection; influenza-like illness; critically-ill patients

ÖZ

İnfluenza veya diğer solunum yolu virüsleri: kritik hastalarda akut solunum yetmezliğinin sebebi olarak önemli midir?

Giriş: Solunum yolu virüsleri yoğun bakım ünitesi yatışı gerektiren ciddi solunum yetmezliğine neden olabilir. Bu çalışmanın amacı, viral enfeksiyonlara bağlı akut solunum yetmezliği (ASY) olan hastalarda etiyolojik ajanları karşılaştırmak, klinik özellikleri ve sonuçları değerlendirmektir.

Materyal ve Metod: Viral serolojisi pozitif olan ASY hastaları geriye dönük olarak değerlendirildi. Kohort, influenza ve diğer solunum virüsleri (DSV), sağ kalanlar ve kaybedilenler olarak alt gruplara ayrılarak incelendi.

Bulgular: Kabul edilen 938 hastanın 319'u ASY olarak takip edildi ve sadece 149 hastanın viral solunum paneli sonuçları mevcuttu. ASY'li 49 hastanın 52 pozitif viral sonucu tespit edildi ve influenza veya DSV'den tek pozitif viral izolatı olan 47 hasta çalışmaya dahil edildi. Bu hastaların \%62'sini influenza grubu ile benzer özelliklere sahip DSV oluşturmaktaydı. Sadece diyabet mellitus influenza grubunda DSV grubuna göre daha fazla görüldü $(p=0.02)$. Toplam YBÜ mortalitesi \%32 idi ve iki grup arasında mortalite açısından fark yoktu $(p=0.42)$. Akut Fizyoloji ve Kronik Sağlık Değerlendirmesi (APACHE) II skoru bağımsız olarak YBÜ mortalitesi ile ilişkili bulundu (OR: 1.25; \%95 GA: 1.04-1.51; $p=0.02$ ).

Sonuç: Bu çalışma, ASY nedeni için influenza ile benzer özelliklere ve mortaliteye sahip diğer solunum virüsleri olasılığının düşünülmesi gerektiğini vurgulamaktadır.

Anahtar kelimeler: Pnömoni; alt solunum yolu enfeksiyonu; grip benzeri hastalık; kritik hastalar

\section{INTRODUCTION}

Respiratory virus infections are characterized by sudden onset of fever, cough, fatigue, myalgia, and headache but are usually self-limiting. However, they are one of the leading causes of community-acquired pneumonia and sometimes exacerbations of asthma or chronic obstructive pulmonary disease (COPD) $(1,2)$. Furthermore, they can also lead to acute respiratory failure (ARF), sepsis, multiple organ failure and death as we have experienced from unfortunate pandemics. Due to limited presence of exact and rapid diagnostic techniques, our knowledge on the real burden of viral infections as the cause of ARF has been limited. Besides, the prevalence of ARF due to viruses varies according to the case definitions, cohorts, seasons, geographical locations and even the diagnostic techniques used. In various studies, the detection rate of respiratory viral agents alters from $16 \%$ to $49 \%$ in patients requiring intensive care unit (ICU) admission due to ARF (3-5).

Influenza pandemics in the last decade raised our awareness and concern about viral causative agents in the pathophysiology of ARF. However, there is still paucity of epidemiological and microbiological data. Despite the fact that some subspecies of influenza virus such as swine origin $\mathrm{H} 1 \mathrm{~N} 1$ and $\mathrm{H} 3 \mathrm{~N} 2$ are the most frequent types of influenza in the influenza sea- son, there is still limited data about other respiratory viral agents such as adenovirus, coronavirus, rhinovirus, respiratory syncytial virus (RSV), human metapneumovirus (hMPV) and parainfluenza Virus. The aim of our study was to evaluate the clinical characteristics and outcomes of patients who were admitted to our ICU with ARF and who had positive respiratory viral panel results according to etiological agents as influenza and other respiratory viruses (ORV).

\section{MATERIALS and METHODS}

Patients who were older than 18 years of age, admitted to the medical ICU between $1^{\text {st }}$ January 2013 and $30^{\text {th }}$ June 2016 due to ARF with positive viral respiratory panel results were retrospectively evaluated.

Age, gender, body mass index (BMI) of patients (classified as underweight $(<18.5)$, normal weight (18.524.9), overweight (25.0-29.9) and obese ( $\geq 30)$ ), smoking history, comorbidities, Charlson Comorbidity Index (CCI) (6), Acute Physiology and Chronic Health Evaluation (APACHE) II score (7), Sequential Organ Failure Assessment (SOFA) scores (8) in the first and last day of the ICU stay, and presence of sepsis and/or septic shock on admission according to Sepsis-3 Definitions (9) and acute respiratory distress syndrome (ARDS) according to Berlin definitions (10) were noted. ARF was defined as a respiratory rate greater than 30 breaths per minute, respiratory distress symp- 
toms, $\mathrm{PaO}_{2}$ lower than $60 \mathrm{mmHg}$ or $\mathrm{SaO}_{2}$ lower than 0.90 on room air or a need for ventilatory support (11). The use of non-invasive (NIMV) or invasive mechanical ventilation (IMV) in the hospital admission, IMV during ICU; antiviral, antibiotic and systemic steroid agents and durations in the ICU hospitalization were recorded. Lung zone counts with infiltration in X-ray and if it was utilized, thorax computerized tomography $(\mathrm{CT})$ evaluations were done as ground glass opacity and consolidation, as well.

Real time polymerase chain reaction (PCR) in Bio-Rad CFX96 TouchTM was used to detect respiratory viruses from nasopharyngeal swab, nasopharyngeal aspirate and bronchoalveolar lavage specimens using Dual Priming Oligonucleotide (DPO ${ }^{\mathrm{TM}}$ ) technology and melting curve analysis method of Tagging Oligonucleotide Cleavage and Extension (TOCE ${ }^{\mathrm{TM}}$ ) technology. The viruses tested by this method were adenovirus ( $A d V)$, influenza $A$ virus (FluA), influenza $B$ virus (FluB), parainfluenza virus1 (PIV1), parainfluenza virus2 (PIV2), parainfluenza virus3 (PIV3), parainfluenza virus4 (PIV4), rhinovirus $A / B / C$ (HRV) and Panel $B$ : respiratory syncytial virus $A$ (RSV $A$ ), respiratory syncytial virus $B$ (RSV $B$ ), bocavirus 1/2/3/4 (HBoV), metapneumovirus (MPV), coronavirus $229 E$ (CoV 229E), coronavirus NL63 (CoV NL63), coronavirus OC43 (CoV OC43) and enterovirus (HEV).

Primary viral infection was considered when respiratory and blood bacterial cultures were negative within first 72 hours during the acute phase of viral ARF. Bacterial co-infection was considered as positive culture results within the first 72 hours in patients with confirmed viral infection. Secondary bacterial infection was considered as positive culture results after 72 hours in patients with confirmed viral infection $(12,13)$. Culture results of blood, catheter, urine, bronchoalveolar lavage and the other sites were noted. Opportunistic infections such as Pneumocystis jiroveci, Cytomegalovirus and Aspergillus species were also assessed. C-reactive protein (CRP), procalcitonin (PCT), lymphocyte, leukocyte and lactate levels at the time of respiratory viral positivity were recorded. Primary outcome variable was ICU mortality. Secondary outcome variables were hospital mortality, ICU and hospital length of stay (LOS).

\section{Statistical Analysis}

Statistical Packages for the Social Sciences v18.0 (SPSS Inc, Chicago, IL) software was used for statistical analyses. Descriptive statistical values of the patients were expressed as number (percentage (\%)) and median (interquartile range). Mann-Whitney $U$ test and Chi-square or Fisher Exact tests were used for group comparisons, where appropriate. Variables significantly related with ICU mortality in bi-variate analysis were examined by logistic regression analysis to determine independent factors related with mortality. Results of logistic regression analysis were indicated as odds ratio (OR) and 95\% Confidence Interval (Cl). Kaplan-Meier curve with log rank was used to determine the effect of virus groups on ICU survival. $\mathrm{p}<0.05$ was considered as statistically significant.

\section{RESULTS}

Among 938 hospitalized patients in the ICU during the study period, $319(34 \%)$ patients were followed up with the diagnosis of ARF and 149 (47\%) patients tested for respiratory viral panel were evaluated.

Fifty-two positive viral results were observed in 49 $(33 \%)$ patients. Two patients in whom influenza A and RSV were detected simultaneously were excluded and 47 patients with single isolates of either influenza or any of the ORV were included in the study. ORV were detected in $29(62 \%)$ of the patients, whereas influenza species were detected in $18(38 \%)$. Median age was 63 (54-75) and 23 (49\%) of them were above 65 years old. Twenty-two of them ( $47 \%$ ) were male. The detection rate of a positive result increased over the years and $26(55.3 \%)$ of them were detected in 2016. Majority of patients were seen in winter $(61.7 \%)$ and spring $(25.5 \%)$. Almost all influenza cases were seen during winter months $(89 \%)$, while ORV had a seasonal distribution and $44.8 \%$ of the cases with ORV were seen in winter followed by spring $(34.5 \%)$, autumn $(13.8 \%)$ and summer $(6.9 \%)(p=0.02)$. Most of the comorbidities were hypertension, malignancy and COPD with a median CCl score of 5 (3-6). Median APACHE II score was 20 (14-25). Admission and last day SOFA scores were 5 (3-7) and 3 (2-12), respectively. On admission, 22 (46.9\%) of patients had sepsis, $12(26.5 \%)$ had septic shock and ARDS was diagnosed in $41(87 \%)$ of cases. Moderate ARDS constituted the main group $(55.3 \%) .40 .4 \%$ of patients had four lung zone infiltration. Most of thorax CT $(55.8 \%)$ revealed ground glass opacity. Systemic steroids were administered to $32(68.0 \%)$ patients due to bronchoconstriction, sepsis and other comorbid conditions. All patients were mechanically ventilated on admission. Overall median NIMV and IMV days were 6 (4-10) and 7 (2.018.5) respectively. 
In the comparison of influenza viruses and ORV, diabetes mellitus (DM) frequency was higher in the influenza group $(p=0.02)$. In addition, mild ARDS was slightly high in influenza group $(p=0.08)$, while moderate ARDS was slightly high in ORV group ( $p=$ 0.07). There was no difference between patients with influenza and ORV regarding other variables. In microbiological evaluation, primary viral, bacterial co-infection, secondary bacterial and opportunistic infections were detected in 23, 45, 51 and 30\% of patients, respectively (Table 1). Mostly encountered bacterial microorganisms were Escherichia coli $(\mathrm{n}=7)$ and Staphylococcus aureus $(\mathrm{n}=5)$; secondary bacterial agents were Acinetobacter baumannii $(n=10)$, Enterococcus faecium $(\mathrm{n}=10)$, Escherichia coli $(\mathrm{n}=$ 7), Klebsiella pneumonia $(\mathrm{n}=7)$ and Pseudomonas aeruginosa $(n=6)$; opportunistic infections agents were Cytomegolavirus $(n=11)$, Aspergillus fumigates $(\mathrm{n}=8)$ and Pneumocystis jiroveci $(\mathrm{n}=2)$, respectively. All of the influenza positive patients received antiviral treatment, while $59.9 \%$ of the patients positive for ORV received antiviral treatment in which one patient with positive RSV result receiving ribavirine in addition to oseltamivir. Except one, all received antibacterial treatment.

Laboratory results are shown in Table 2. Almost 90\% of cases had lymphopenia with no difference between groups. Lactate level was higher in the influenza group ( $p=0.05$ ) and ratio of $\mathrm{PaO}_{2} / \mathrm{FiO}_{2}$ was lower in the ORV group $(p=0.02)$. Other laboratory parameters were similar (Table 2). In the comparison of primary viral infection subgroup with others in subgroup analysis; median CRP (4.0 (2.0-30.0) vs. 13.0 (9.4-21.5), $\mathrm{p}=0.29)$ did not differ between groups. However, PCT (0.14 (0.12-0.26) vs. 0.28 (0.15-0.77), $\mathrm{p}=0.08$ ) levels were slightly lower in primary viral infection group.

Rhinovirus was the most frequent agent in ORV group $(21 \%)$. ICU mortality in cases with parainfluen$z a$ and $h M P V$ were $50 \%$, whereas there was no mortality in cases with RSV and adenovirus (Figure 1). Overall ICU and hospital mortality were $\% 32$ and $\% 40$; and median ICU length of stay were 11 (6-29) and 23 (14-47) days, respectively (Table 3).

Kaplan Meier survival analysis did not reveal any difference in ICU mortality, as well $(p=0.48)$ (Figure 2). Bi-variate analysis of all parameters indicated that ICU survival was better in patients who were older than 65 years old $(p=0.04)$; who had COPD $(p=0.02)$ and high $\mathrm{PaO}_{2} / \mathrm{FiO}_{2}$ ratio $(\mathrm{p}=0.002)$, whereas patients with high APACHE II score $(p=0.004)$, SOFA score $(p=0.02)$ and PCT level $(p=0.02)$ had poorer prognosis (Table 4). Additionally, in subgroup analysis, primary viral infection was encountered more in COPD subgroup $(n=18)(p=0.01)$, whereas secondary bacterial infections were more in non-COPD subgroup $(n=29)(p=0.05)$. Sub-group analysis did not reveal any statistical difference for ICU mortality for primary viral infection, co-infection or bacterial secondary infection sub-groups $(p=0.46, p=0.13$, $p=0.20$, respectively). Logistic regression analysis showed that only APACHE II score was independently associated with ICU mortality (for each point increase in APACHE II score, OR: $1.25 ; 95 \% \mathrm{Cl}$ : 1.04-1.51; $p=0.02$ ) (Table 5; only parameters with significant results were given).

\section{DISCUSSION}

To the best of our knowledge; this is the first study that primarily aimed to compare general characteristics of patients with influenza and ORV separately, up to date. Our study verified that ORV were more frequently identified than influenza with comparable characteristics and mortality which shows that non-influenza agents are as important as influenza species in terms of etiology in adult patients hospitalized in a tertiary hospital medical ICU due to respiratory failure. Similar to our study, subgroup analysis of previously published studies revealed that ORV constituted major group of viral etiology with $64-80 \%$ prevalence, with no comparisons between influenza and ORV in those studies $(11,14,15)$.

Current study showed that patients with influenza and ORV had similar characteristics (Table 1) except that in patients with influenza DM was more frequent than non-influenza agents $(p=0.02)$. DM is a wellknown risk factor for influenza virus infection. Patients with DM have six times higher probability to be hospitalized during influenza epidemics in comparison with non-diabetic patients (16). The prevalence of hospitalization due to influenza in diabetic patients varies from $6 \%$ to $34.2 \%(17-20)$.

There is a debate in the use of PCT for differentiation of bacterial from nonbacterial infections. It is suggested that PCT may be used in the differentiation of bacterial and viral etiology in respiratory infections where CRP is supposed to be high in either (21). However, at present, the evidence for the use of PCT level does not support the use of PCT alone to differ- 
Influenza or other respiratory viruses: does it matter as the cause of acute respiratory failure in the critically-ill patients?

\begin{tabular}{|c|c|c|c|c|}
\hline & $\begin{array}{c}\text { All } \\
(n=47)\end{array}$ & $\begin{array}{c}\text { Influenza } \\
(\mathbf{n}=18)\end{array}$ & $\begin{array}{c}\text { ORV } \\
(n=29)\end{array}$ & $\mathbf{p}$ \\
\hline Age *, years & $63.0(54.0-75.0)$ & $67.0(56.5-84.5)$ & $63.0(51.5-71.5)$ & 0.17 \\
\hline Patients $>65$ years of age & $23(49.0)$ & $9(50.0)$ & $14(48.0)$ & 0.90 \\
\hline Male sex & $22(47.0)$ & $8(44.0)$ & $14(48.0)$ & 0.80 \\
\hline Years & & & & 0.21 \\
\hline 2013 & $3(6.4)$ & $1(5.6)$ & $2(6.9)$ & \\
\hline 2014 & $6(12.8)$ & - & $6(20.7)$ & \\
\hline 2015 & $12(25.5)$ & $5(27.8)$ & $7(24.1)$ & \\
\hline 2016 & $26(55.3)$ & $12(66.7)$ & $14(48.3)$ & \\
\hline Seasons & & & & 0.02 \\
\hline Winter & $29(61.7)$ & $16(89.0)$ & $13(44.8)$ & \\
\hline Spring & $12(25.5)$ & $2(11.0)$ & $10(34.5)$ & \\
\hline Autumn & $4(8.5)$ & - & $4(13.8)$ & \\
\hline Summer & $2(4.3)$ & - & $2(6.9)$ & \\
\hline $\mathrm{BMI}^{*}, \mathrm{~kg} / \mathrm{m}^{2}$ & $27.0(23.2-31.2)$ & $27.3(23.0-31.2)$ & $27.0(23.2-31.0)$ & 0.98 \\
\hline Underweight & $4(8.5)$ & $1(5.5)$ & $3(10.4)$ & \\
\hline Normal & $14(30.0)$ & $7(39.0)$ & $7(24.2)$ & \\
\hline Overweight & $15(32.0)$ & $3(17.0)$ & $12(41.4)$ & \\
\hline Obese & $13(29.5)$ & $6(33.0)$ & $7(24.0)$ & \\
\hline \multicolumn{5}{|l|}{ Comorbidities } \\
\hline Hypertension & $20(43.0)$ & $10(55.5)$ & $10(34.5)$ & 0.15 \\
\hline Malignancy & $19(40.0)$ & $6(33.0)$ & $13(45.0)$ & 0.43 \\
\hline COPD & $18(38.0)$ & $7(39.0)$ & $11(38.0)$ & 0.95 \\
\hline CAD & $17(35.0)$ & $8(44.0)$ & $9(31.0)$ & 0.35 \\
\hline DM & $13(28.0)$ & $9(50.0)$ & $4(14.0)$ & 0.02 \\
\hline CKD & $6(13.0)$ & $1(5.5)$ & $5(17.0)$ & 0.34 \\
\hline Rheumatological disease & $5(11.0)$ & $1(5.5)$ & $4(14.0)$ & 0.64 \\
\hline Neuromuscular disease & $3(6.0)$ & $2(11.0)$ & $1(3.4)$ & 0.55 \\
\hline Chronic liver disease & $1(2.0)$ & $0(0.0)$ & $1(3.4)$ & 1.00 \\
\hline $\mathrm{CCl}^{*}$ & $5.0(3.0-6.0)$ & $6.0(4.0-7.0)$ & $4.0(3.0-6.0)$ & 0.20 \\
\hline APACHE II score* & $19.0(14.0-25.0)$ & $20.0(16.0-28.0)$ & $18.0(13.0-25.0)$ & 0.51 \\
\hline \multicolumn{5}{|l|}{ SOFA score* } \\
\hline Admission & $5.0(3.0-7.0)$ & $5.0(3.0-9.0)$ & $6.0(3.0-7.0)$ & 0.88 \\
\hline Last day & $3.0(2.0-12.0)$ & $3.0(3.0-13.0)$ & $3.0(1.0-11.0)$ & 0.45 \\
\hline Sepsis on admission & $22(47.0)$ & $9(50.0)$ & $13(45.0)$ & 0.73 \\
\hline Septic shock on admission & $12(25.5)$ & $4(22.0)$ & $8(28.0)$ & 0.75 \\
\hline \multicolumn{5}{|l|}{ Mechanical Ventilation } \\
\hline NIMV & $33(70.0)$ & $14(78.0)$ & $19(65.5)$ & 0.37 \\
\hline IMV & $14(30.0)$ & $4(22.0)$ & $10(35.5)$ & 0.37 \\
\hline \multicolumn{5}{|l|}{ During ICU stay } \\
\hline IMV & $18(38.3)$ & $8(44.4)$ & $10(35.5)$ & 0.50 \\
\hline \multicolumn{5}{|l|}{ Overall duration*, days } \\
\hline NIMV & $6.0(4.0-10.0)$ & $6.0(4.0-10.0)$ & $6.0(4.5-10.0)$ & 0.72 \\
\hline IMV & $7.0(2.0-18.5)$ & $11.0(2.5-29.0)$ & $6.5(2.0-19.5)$ & 0.49 \\
\hline ARDS on admission & $41(87.0)$ & $15(83.0)$ & $26(90.0)$ & 0.28 \\
\hline Mild & $11(23.4)$ & 7 (39.0) & $4(13.7)$ & 0.08 \\
\hline Moderate & $26(55.3)$ & $7(39.0)$ & $19(65.5)$ & 0.07 \\
\hline Severe & $4(8.5)$ & $1(5.5)$ & $3(10.3)$ & 1.00 \\
\hline
\end{tabular}

392 Tuberk Toraks 2020;68(4):388-398 
Table 1. General characteristics of patients (continue)

\begin{tabular}{|c|c|c|c|c|}
\hline & $\begin{array}{c}\text { All } \\
(n=47)\end{array}$ & $\begin{array}{l}\text { Influenza } \\
(n=18)\end{array}$ & $\begin{array}{c}\text { ORV } \\
(n=29)\end{array}$ & $\mathbf{p}$ \\
\hline \multicolumn{4}{|l|}{ Lung infiltration zone numbers } & \multirow[t]{5}{*}{0.62} \\
\hline 1 & $5(10.6)$ & $2(11.0)$ & $3(10.3)$ & \\
\hline 2 & $12(25.5)$ & $5(28.0)$ & $7(24.0)$ & \\
\hline 3 & $5(10.6)$ & $1(5.5)$ & $4(13.8)$ & \\
\hline 4 & $19(40.4)$ & $9(50.0)$ & $10(34.5)$ & \\
\hline Thorax CT & $34(72.3)$ & $11(61.0)$ & $23(79.3)$ & \multirow[t]{3}{*}{0.38} \\
\hline Ground glass opacity & $19(55.8)$ & $8(73.0)$ & $11(48.0)$ & \\
\hline Consolidation & $9(26.5)$ & $2(18.0)$ & $7(30.4)$ & \\
\hline Systemic steroid & $32(68.0)$ & $11(61.0)$ & $21(72.4)$ & 0.51 \\
\hline Antiviral administration & $35(74.4)$ & $18(100.0)$ & $17(59.0)$ & $<0.01$ \\
\hline Duration & $5(5-5)$ & $5(5-8)$ & $5(5-5)$ & 0.32 \\
\hline Antibiotic administration & $46(98.0)$ & $17(94.4)$ & $29(100.0)$ & 0.38 \\
\hline Primary viral infection & $11(23.0)$ & $4(22.0)$ & $7(24.0)$ & 1.00 \\
\hline Bacterial co-infection & $21(45.0)$ & $9(50)$ & $12(41.0)$ & 0.56 \\
\hline Secondary bacterial infection & $24(51.0)$ & $11(61)$ & $13(45)$ & 0.28 \\
\hline Opportunistic infections & $14(30.0)$ & $5(28.0)$ & $9(31.0)$ & 0.81 \\
\hline \multicolumn{5}{|c|}{$\begin{array}{l}\text { * Continuous variables are represented as median (IQR), all other categorical variables as n (\%). } \\
\text { ORV: Other respiratory viruses, BMI: Body mass index, COPD: Chronic obstructive pulmonary disease, CAD: Coronary artery disease, DM: Diabetes } \\
\text { mellitus, CKD: chronic kidney disease, CCI: Charlson Comorbidity Index, APACHE: Acute Physiology and Chronic Health Evaluation, SOFA: Sequen- } \\
\text { tial organ failure assessment, NIMV: Non-invasive mechanical ventilation, IMV: Invasive mechanical ventilation, ARDS: Acute respiratory distress } \\
\text { syndrome, CT: Computerized tomography, IQR: Interquartile range. }\end{array}$} \\
\hline
\end{tabular}

Table 2. Laboratory results of patients

\begin{tabular}{|c|c|c|c|c|}
\hline Parameters & All $(n=47)$ & Influenza $(n=18)$ & ORV $(n=29)$ & $\mathbf{p}$ \\
\hline CRP* (0.0-0.8), mg/dL & $13.0(4.0-24.5)$ & $18.30(1.35-55.20)$ & $12.0(3.0-21.4)$ & 0.15 \\
\hline $\begin{array}{l}\text { PCT* }^{*} \\
(0.0-0.1), \mathrm{ng} / \mathrm{mL}\end{array}$ & $0.23(0.13-0.75)$ & $0.31(0.02-85.73)$ & $0.19(0.12-0.49)$ & 0.08 \\
\hline $\begin{array}{l}\text { Lymphocyte count* (1300-3500), /mL } \\
\text { Lymphopenia }\end{array}$ & $\begin{array}{c}500(300-800) \\
42(89.4)\end{array}$ & $\begin{array}{l}550(200-1400) \\
15(83.3)\end{array}$ & $\begin{array}{l}500(300-750) \\
27(93.1)\end{array}$ & $\begin{array}{l}0.49 \\
0.36\end{array}$ \\
\hline Leukocyte count* (4300-10300), /mL & $9900(6000-12100)$ & $9500(2300-17400)$ & $9000(3600-12000)$ & 0.48 \\
\hline Leukopeni & $9(19.1)$ & $1(5.6)$ & $8(27.6)$ & 0.12 \\
\hline Leukocytosis & $19(40.4)$ & $8(44.4)$ & $11(37.9)$ & 0.66 \\
\hline Lactate* $(0.9-1.7), \mathrm{mMol} / \mathrm{L}$ & $1.8(1.3-3.0)$ & $2.0(1.1-5.1)$ & $1.7(1.2-2.7)$ & 0.05 \\
\hline $\mathrm{PaO}_{2} / \mathrm{FiO}_{2}^{*}$ & $184(152-218)$ & $220(167-258)$ & $171(147-199)$ & 0.02 \\
\hline Mild ARDS & $218(209-250)$ & $242(220-256)$ & $211(204-214)$ & 0.06 \\
\hline Moderate ARDS & $166(149-184)$ & 167 (149-193) & $166(148-183)$ & 0.82 \\
\hline Severe ARDS & $79(66-98)$ & $65(65-65)$ & $90(68-90)$ & 0.18 \\
\hline
\end{tabular}

entiate accurately between viral and bacterial causes (22). In this study, subgroup analysis of patients with primary viral infections revealed no difference in terms of CRP levels (median (4.0 (2.0-30.0) vs. 13.0 (9.4-21.5), $\mathrm{p}=0.29)$, however a tendency towards lower PCT levels $(0.14(0.12-0.26)$ vs. 0.28 (0.15$0.77), \mathrm{p}=0.08)$. $\mathrm{PO}_{2} / \mathrm{FiO}_{2}$ ratio in ORV group was lower than influenza group. Although it wasn't significant, most of moderate and severe ARDS patients were from ORV group. It can be postulated that 


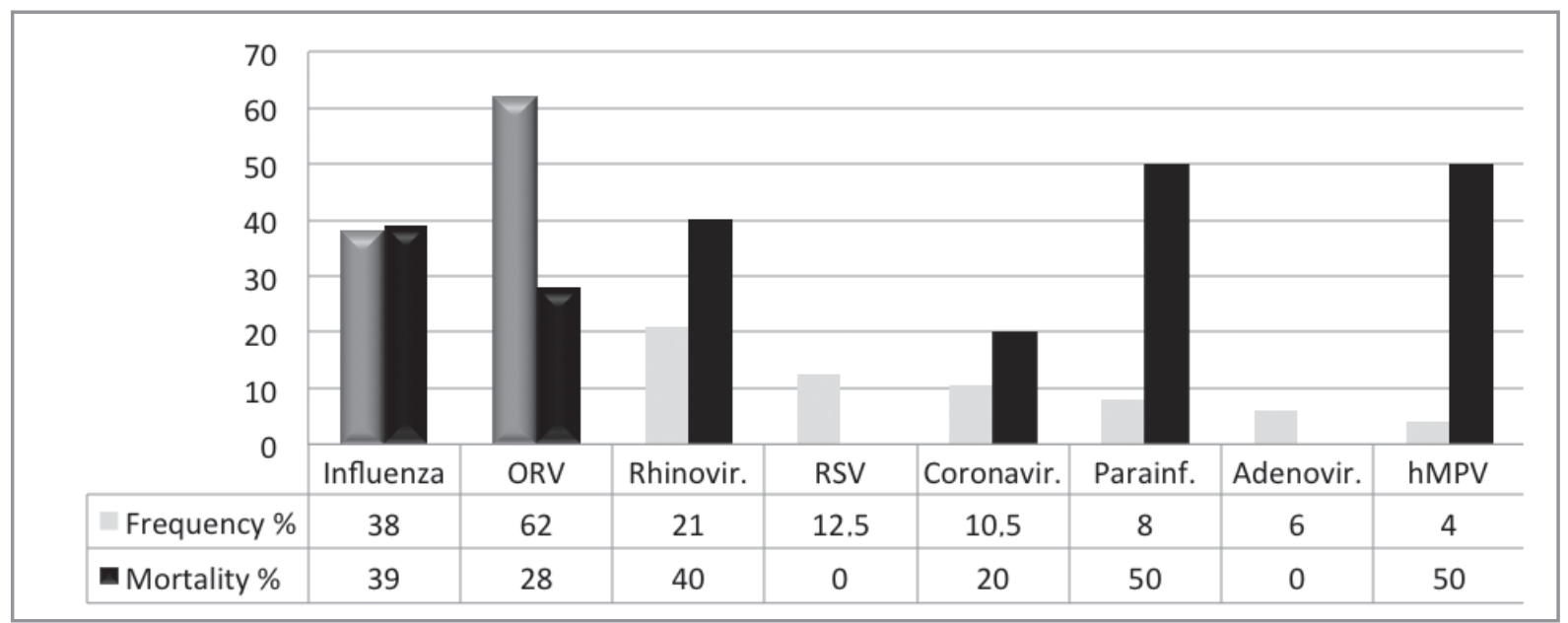

Figure 1. Distribution of viral agents and their mortality rates.

Table 3. Outcome variables

\begin{tabular}{|lcccc|} 
& All $(\mathbf{n}=\mathbf{4 7})$ & Influenza $(\mathbf{n}=\mathbf{1 8})$ & ORV $(\mathbf{n}=\mathbf{2 9})$ & $\mathbf{p}$ \\
\hline ICU mortality & $15(32.0)$ & $7(39.0)$ & $8(28.0)$ & 0.42 \\
Hospital mortality & $19(40.0)$ & $11(55.0)$ & $10(34.5)$ & 0.29 \\
ICU LOS & $11.0(6.0-29.0)$ & $11.0(5.0-26.0)$ & $11.0(8.0-30.0)$ & 0.73 \\
Hospital LOS & $23.0(14.0-47.0)$ & $26.0(13.0-67.0)$ & $23.0(13.5-44.5)$ & 0.98 \\
\hline
\end{tabular}

Results are represented as median (IQR), all other categorical variables as $\mathrm{n}(\%)$.

ORV: Other respiratory viruses, ICU: Intensive care unit, LOS: Length of stay, IQR: Interquartile range.

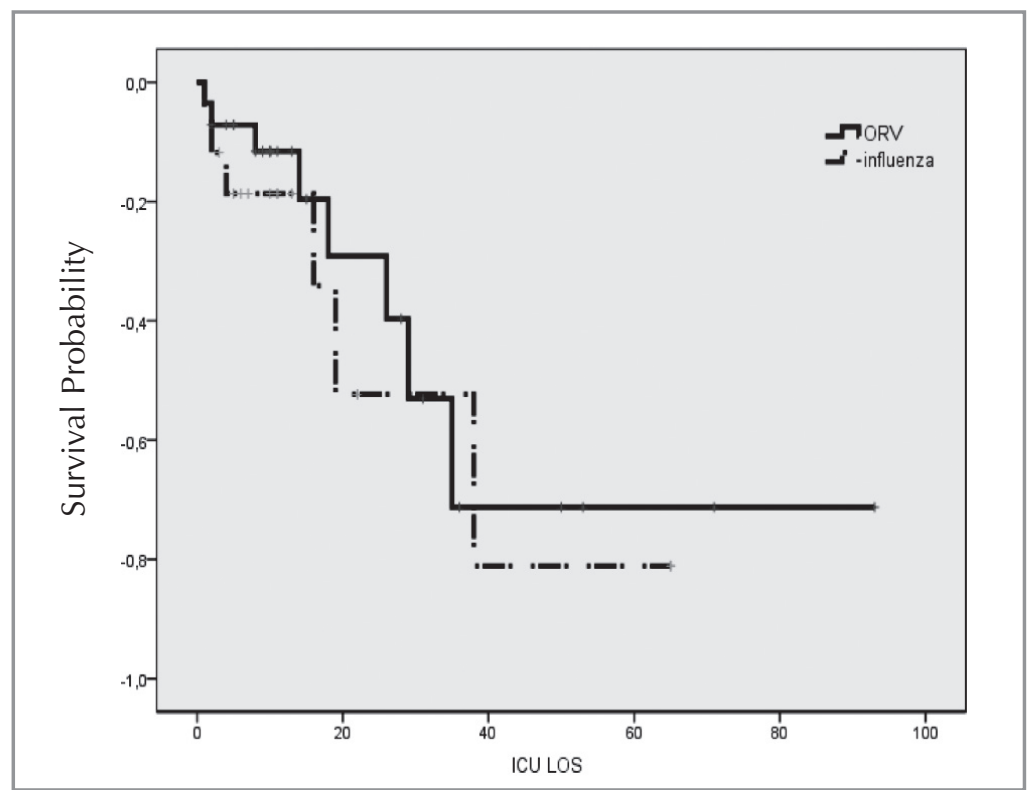

Figure 2. Kaplan Meier survival curve.

Kaplan Meier survival analysis according to viral groups as influenza and ORV did not reveal difference in ICU mortality $(\mathrm{p}=0.48)$.

ORV: Other respiratory viruses, LOS: Length of stay. 
Halaçlı B, Hancı P, Ortaç Ersoy E, Öcal S, Tanrı̈ver MD, Topeli A.

Table 4. Statistically significant admission variables in bi-variate analysis comparing ICU survivors and non-survivors

\begin{tabular}{|c|c|c|c|}
\hline Significant Variables & Survivors $(n=32)$ & Non-survivors $(n=15)$ & $\mathbf{p}$ \\
\hline Patients $>65$ years old & $19(59.0)$ & $4(27.0)$ & 0.04 \\
\hline COPD & $16(50)$ & $2(13)$ & 0.02 \\
\hline APACHE II score* & $17.0(12.0-24.0)$ & $25.0(20.0-28.0)$ & 0.004 \\
\hline SOFA score* & $4.0(2.0-7.0)$ & $7.0(6.0-8.0)$ & 0.02 \\
\hline $\mathrm{PCT}^{*}(0.0-0.1), \mathrm{ng} / \mathrm{mL}$ & $0.19(0.12-0.34)$ & $0.60(0.22-1.93)$ & 0.02 \\
\hline $\mathrm{PaO}_{2} / \mathrm{FiO}_{2} *$ & $197(166-252)$ & $147(121-187)$ & 0.002 \\
\hline
\end{tabular}

Table 5. Multivariate analysis of factors influenced mortality

\begin{tabular}{|c|c|c|c|}
\hline Independent Variables & Odds Ratio & 95\% Confidence Interval & $\mathbf{p}$ \\
\hline APACHE II score (for each value) & 1.25 & $1.04-1.51$ & 0.02 \\
\hline ORV vs. Influenza (reference ORV) & 3.05 & $0.33-27.77$ & 0.32 \\
\hline $\begin{array}{l}\mathrm{PaO}_{2} / \mathrm{FiO}_{2}<2 \mathrm{OO} \\
\text { (reference } \mathrm{PaO}_{2} / \mathrm{FiO}_{2}>200 \text { ) }\end{array}$ & 3.01 & $0.23-39.30$ & 0.40 \\
\hline SOFA score (for each value) & 1.03 & $0.83-1.28$ & 0.78 \\
\hline РCТ (for each 1 ng/mL) & 0.98 & $0.93-1.03$ & 0.32 \\
\hline Patients $>65$ years old & 0.32 & $0.03-3.32$ & 0.34 \\
\hline COPD & 0.15 & $0.01-1.83$ & 0.14 \\
\hline
\end{tabular}

non-influenza agents must be considered as much as influenza and management should be directed properly even if therapeutic options are limited for ORV. All of our patients with influenza received antiviral treatment as expected. In the other group, 59\% of the patients received antiviral treatment, since $\mathrm{WHO}$ and Centers for Disease Control and Prevention (CDC) recommend empiric oseltamivir therapy for while the diagnostic tests are pending, in critically-ill high-risk patients (23).

Although seasonal influenza is a self-limited infection with relative annual mortality rate of only 1.4 to 16.7 deaths per 100.000 persons in the general population, patients older than 65 years of age, living at nursing homes, with pregnancy, with chronic medical conditions, with immune compromised status and with obesity have increased mortality and higher rate of ICU admissions. In contrast to this characteristic of seasonal influenza, in $2009 \mathrm{H} 1 \mathrm{~N} 1$ pandemic, mortality rate was 100-5000/100.000 in all over the world. In a study by Jain et al. (18) about hospitalized patients during 2009 H1N1 pandemic in United
States, 25\% of the enrolled 272 patients were admitted to an intensive care unit. Patients who were under the age of 18 years consisted $45 \%$ of cases and only $5 \%$ were 65 years of age or older. Median age of non-survivors was 26 years. Estimated global mortality study by Dawood et al (24) indicated that higher mortality due to respiratory reasons due to $\mathrm{H} 1 \mathrm{~N} 1$ virus was seen more frequently in younger patients. Possible explanations of this contrast result in comparison with seasonal influenza could be higher susceptibility of younger patients to viruses and lack of vaccination. In our cohort, ICU mortality was $32 \%$. Survivors were older than non-survivors as seen during 2009 pandemic. In addition, presence of COPD was encountered more in survivors. Wellknown risk factor for COPD exacerbation is respiratory infections, up to $60 \%$ of COPD exacerbations being secondary to the respiratory viruses (25). Subgroup comparison of patients with and without COPD showed that primary viral etiology was higher in COPD group $(n=18)$ than in non-COPD $(n=29)$, in our cohort $(p=0.01)$. Moreover, secondary bacte- 
rial infections were slightly more encountered in patients without COPD $(p=0.05)$. The lower mortality observed in COPD patients could be due to the fact that viral etiology as the cause of exacerbation carries better prognosis than bacterial causes (3). Higher APACHE II, admission SOFA scores and PCT levels and lower $\mathrm{PaO}_{2} / \mathrm{FiO}_{2}$ ratio were associated with higher mortality in bi-variate analysis. However, multivariate analysis disclosed that only APACHE II score was independently associated with ICU outcome.

Distribution of viral agents in our study showed that ORV is the leading group for viral ARF (Figure 1). Among them, rhinovirus was the most frequent (35\%) agent. Rhinovirus is the most encountered reason of viral upper respiratory tract infections (26). A retrospective study (27) revealed that mortality rate of rhinovirus cases could reach to $30 \%$ which was $40 \%$ in our cohort. Although RSV is the most known cause of lower respiratory tract infections in pediatric age, it is generally not identified in adults (28). In this study, almost $21 \%$ of ORV was RSV with no fatality similar to adenovirus.

Global Influenza Hospital Surveillance Network (GIHSN) has been founded for recording the influenza infections in acute care setting (29). Since influenza A (H1N1) pandemic observed in 2009, there have been several case series about influenza-associated critical illness. In a study from Ortiz et al. (30), it was estimated that influenza-associated events account for $1.3 \%$ of all critical illness hospitalizations and $3.4 \%$ of critical illness hospitalizations during the influenza season. They found that influenza diagnosis in the adult ICUs were underestimated. Potential explanations for this result are lack of common case definitions, unavailability of timely appropriate sensitive tests and belief of ineffectiveness of influenza treatment. In our cohort, only $47 \%$ of ARF patients were assessed for the viral serology which could prevent to reflect the exact burden of viral etiology. A multicenter surveillance study by Tanriover et al (31), in the context of GIHSN in Turkey pointed out that influenza was detected $18.7 \%$ of 1351 screened acutely-ill patients with influenza-like disease and among them $32.6 \%$ were admitted to ICU. In our study, almost $5 \%$ of 939 patients admitted to ICU were detected with viral etiology for ARF. Patient numbers tended to increase over the study duration, most patients being detected during the last 6 -months of the study period probably due to increased awareness and availability of more appropriate and timely sensitive tests.

The main limitations of this study are relatively low patient numbers and its single center retrospective design which prevents generalization of findings. Unfortunately, we don't have any information about subtypes of influenza species like H1N1 or H3N2. As molecular assays may detect influenza viral RNA in respiratory tract specimens for longer periods after illness onset, the cause and effect relation cannot be put with $100 \%$ accuracy (32). Hence, co-infection might be purely bacterial infection and the outcome might be affected only by bacterial etiology. Unknown information about where samples were sent from such as nasal, oropharynx and lower respiratory ways is another limitation. Tropism of some viruses to different parts of the respiratory tract might interfere with interpretation of the results. The probability of co-incidental upper respiratory viral infection should be kept in mind. Unfortunately, we do not have any data about how many patients received antimicrobial agents before ICU admission. Therefore, some patients might have had false-negative findings regarding bacterial growth, and the proportion of patients infected by the virus only, might have been overestimated. We also do not know the vaccination history of patients which could have changed the prevalence and outcomes in each group.

\section{CONCLUSION}

This study draws attention to consider possibility of other respiratory viruses more than influenza species with comparable characteristics and similar ICU mortality rates. These results need to be confirmed by multicenter surveillance studies with more patients using standardized highly sensitive tests. By this way, it could be possible to understand the real burden and causality of ORV for ARF in critically ill patients.

Ethical Committee Approval: The approval for this study was obtained from Hacettepe University Institutional Ethical Committee (Decision no: 16/59809 Date: 27.09.2016).

\section{CONFLICT of INTEREST}

The authors of this original article declare that they have no conflict of interest. 


\section{AUTHORSHIP CONTRIBUTIONS}

Concept/Design: $\mathrm{BH}, \mathrm{PH}, \mathrm{EO}, \mathrm{SO}$

Analysis/Interpretation: EO, SO, MDT, AT

Data Acquisition: $\mathrm{BH}, \mathrm{PH}$

Writting: $\mathrm{BH}, \mathrm{PH}, \mathrm{AT}$

Critical Revision: All of authors

Final Approval: All of authors

\section{REFERENCES}

1. Nicholson KG, Wood JM, Zambon M. Influenza. Lancet 2003; 362: 1733-45.

2. ANZIC Influenza Investigators. Critical care services and 2009 H1N1 influenza in Australia and New Zealand. N Engl J Med 2009; 361(20): 1925-34.

3. Daubin C, Parienti JJ, Vincent $S$, Vabret $A$, du Cheyron D, Ramakers $M$, et al. Epidemiology and clinical outcome of virus-positive respiratory samples in ventilated patients: a prospective cohort study. Crit Care 2006; 10(5): R142.

4. Wiemken T, Peyrani P, Bryant K, Kelley RR, Summersgill J, Arnold $F$, et al. Incidence of respiratory viruses in patients with community-acquired pneumonia admitted to the intensive care unit: results from the Severe Influenza Pneumonia Surveillance (SIPS) project. Eur J Clin Microbiol Infect Dis 2013; 32(5): 705-10.

5. Choi SH, Hong SB, Ko GB, Lee Y, Park HJ, Park SY, et al. Viral infection in patients with severe pneumonia requiring intensive care unit admission. Am J Respir Crit Care Med 2012; 186(4): 325-32.

6. Charlson ME, Pompei P, Ales KL, MacKenzie CR. A new method of classifying prognostic comorbidity in longitudinal studies: development and validation. J Chronic Dis 1987; 40(5): 373-83.

7. Knaus WA, Draper EA, Wagner DP, Zimmerman JE. APACHE II: a severity of disease classification system. Crit Care Med 1985; 13 (10): 818-29.

8. Vincent IL, Moreno R, Takala J, Willatts S, De Mendonça A, Bruining H, et al. The SOFA (Sepsis-related Organ Failure Assessment) score to describe organ dysfunction/failure. Intensive Care Med 1996; 22: 707-10.

9. Singer $M$, Deutschman CS, Seymour CW, Shankar-Hari M, Annane D, Bauer M, et al. The third international consensus definitions for sepsis and septic shock (Sepsis-3). JAMA 2016; 315(8): 801-10.

10. ARDS Definition Task Force, Ranieri VM, Rubenfeld GD, Thompson BT, Ferguson ND, Caldwell E, Fan E, et al. Acute respiratory distress syndrome: the Berlin Definition. JAMA 2012; 307(23): 2526-33.

11. Schnell D, Gits-Muselli M, Canet E, Lemiale V, Schlemmer $B$, Simon $F$, et al. Burden of respiratory viruses in patients with acute respiratory failure. J Med Virol 2014; 86 (7): 198-202.
12. Rice $T W$, Rubinson L, Uyeki $T M$, Vaughn $F L$, John $B B$, Miller RR, et al. Critical illness from 2009 pandemic influenza $A$ virus and bacterial coinfection in the United States. Crit Care Med 2012; 40: 1487-98.

13. Martín-Loeches I, Sanchez-Corral A, Diaz E, Granada RM, Zaragoza $R$, Villavicencio $C$, et al. Community-acquired respiratory coinfection in critically ill patients with pandemic 2009 influenza A(H1N1) virus. Chest 2011; 139: 555-62.

14. Visseaux B, Burdet C, Voiriot G, Lescure FX, Chougar T, Brugière $O$, et al. Prevalence of respiratory viruses among adults, by season, age, respiratory tract region and type of medical unit in Paris, France, from 2011 to 2016. PLos One 2017 Jul 14; 12(7): e0180888.

15. van Someren Gréve F, Schultz MJ, de Jong MD, Juffermans NP. Influenza and other respiratory viruses are underdiagnosed in critically ill patients. Crit Care Med 2015; 43 (4): e117.

16. Klekotka RB, Mizgała E, Król W. The etiology of lower respiratory tract infections in people with diabetes. Pneumonol Alergol Pol 2015; 83(5): 401-8.

17. Rodríguez-Valero M, Prado Calleros HM, Bravo Escobar GA, Valdez Vázquez RR, Figueroa Moreno R, Martínez Montes $G$, et al. Difference between early clinical features of swine origin A H1N1 influenza confirmed and not confirmed infection in Mexico. I Infect Dev Ctries 2012; 6 (4): 302-10.

18. Jain S, Kamimoto L, Bramley AM, Schmitz AM, Benoit SR, Louie J, et al. Hospitalized patients with 2009 H1N1 influenza in the United States, April-June 2009. N Engl J Med 2009; 12: 1935-44.

19. Miller AC, Subranian RA, Safi $F$, Sinert R, Zehtabchi $S$, Elamin EM. Influenza A 2009 (H1N1) virus in admitted and critically ill patients. I Intensive Care Med 2011; 27: 25-31.

20. Shorr AF, Fisher K, Micek ST, Kollef MH. The Burden of Viruses in Pneumonia Associated With Acute Respiratory Failure: An Underappreciated Issue. Chest 2017; pii: S0012-3692(17)33236-1.

21. Gilbert DN. Procalcitonin as a biomarker in respiratory tract infection. Clin Infect Dis 2011; 52(suppl 4): 346-50.

22. Self WH, Grijalva CG, Williams DJ, Woodworth A, Balk $R A$, Fakhran $S$, et al. Procalcitonin as an early marker of the need for invasive respiratory or vasopressor support in adults with community-acquired pneumonia. Chest 2016; 150(4): 819-28.

23. Fiore AE, Fry A, Shay D, Gubareva L, Bresee JS, Uyeki TM, Centers for Disease Control and Prevention (CDC). Antiviral agents for the treatment and chemoprophylaxis of influenza-recommendations of the Advisory Committee on Immunization Practices (ACIP). MMWR Recomm Rep 2011; 60: 1-24. 
24. Dawood FS, Iuliano AD, Reed C, Meltzer MI, Shay DK, Cheng PY, et al. Estimated global mortality associated with the first 12 months of 2009 pandemic influenza A H1N1 virus circulation: a modelling study. Lancet Infect Dis 2012; 12(9): 687-95.

25. Dimopoulos G, Lerikou M, Tsiodras S, Chranioti A, Perros E, Anagnostopoulou U, et al. Viral epidemiology of acute exacerbations of chronic obstructive pulmonary disease. Pulm Pharmacol Ther 2012 Feb; 25(1): 12-8.

26. Proud D, Naclerio RM, Gwaltney JM, Hendley JO. Kinins are generated in nasal secretions during natural rhinovirus colds. J Infect Dis 1990; 161(1): 120-3.

27. Kraft CS, Jacob JT, Sears MH, Burd EM, Caliendo AM, Lyon GM. Severity of human rhinovirus infection in immunocompromised adults is similar to that of 2009 H1N1 influenza. J Clin Microbiol 2012; 50(3): 1061-3.

28. Falsey $A R$, Walsh EE. Respiratory syncytial virus infection in adults. Clin Microbiol Rev 2000; 13(3): 371-84.
29. Puig-Barberà J, Tormos A, Sominina A, Burtseva E, Launay $O$, Ciblak MA, et al. First-year results of the Global Influenza Hospital Surveillance Network: 2012-2013 Northern hemisphere influenza season. BMC Public Health 2014; 14: 564.

30. Ortiz JR, Neuzil KM, Shay DK, Rue TC, Neradilek MB, Zhou $\mathrm{H}$, et al. The burden of influenza-associated critical illness hospitalizations. Crit Care Med 2014; 42(11): 2325-32.

31. Tanriover MD, Bagci Bosi T, Ozisik L, Bilgin E, Güzel Tunçcan Ö, Özgen Ö, et al. Poor outcomes among elderly patients hospitalized for influenza-like illness. Curr Med Res Opin 2018; 34(7): 1201-7.

32. Merckx J, Wali R, Schiller I, Caya C, Gore GC, Chartrand $C$, et al. Diagnostic Accuracy of novel and traditional rapid tests for influenza infection compared with reverse transcriptase polymerase chain reaction: a systematic review and meta-analysis. Ann Intern Med 2017; 167(6): 394409 . 